\title{
音楽ホールにおける音に包まれた感じに対応する物理指標の検討 \\ A STUDY ON NEW OBJECTIVE MEASURE CORRESPONDING TO LISTENER ENVELOPMENT IN CONCERT HALLS
}

\author{
末廣大地*，翁長＼cjkstart博**，池田哲朗*** \\ Daichi SUEHIRO, Hiroshi ONAGA and Tetsuo IKEDA
}

\begin{abstract}
A subjective experiment on listener envelopment (LEV) was carried out using synthesized sound fields in an anechoic room. The results are as follows. 1) The largest LEV was observed around azimuth 90 degree as to arriving direction of reverberation. 2) Longer reverberation time makes LEV larger. 3) Larger energy of reverberation makes LEV larger. 4) Left-to-right imbalance of reverberant energy makes LEV smaller. 5) Front-to-back imbalance of reverberant energy makes LEV smaller. 6) Reverberation arriving from frontal direction makes LEV larger than from behind. The results 1) to 5) generally coincide with previous works, but result 6) differs from them. Based on these results, SDR (spatial distribution of reverberation) was proposed as a measure of LEV. SDR shows higher correlation with the experimental results on LEV than already proposed measure LG by Bradley or SBTs by Hanyu.
\end{abstract}

Keywords : Listener envelopment, Spatial impression, Concert hall 音に包まれた感じ、空間印象、音楽ホール

\section{1.はじめに}

「音に包まれた感じ」(Listener Envelopment: LEV)は「みかけの音源 の幅」(Auditory Source Width: ASW) とともに音楽ホールの音響の評価 における重要な空間印象の要素感覚の一つである1),2)。LEVにかかわ る音場のパラメータとして、残響時間や反射音の遅れ時間といった 時間構造、反射音および残響音の到来方向といった空間構造などが あげられている ${ }^{3), 4), 5)}$

これらの音場パラメータを制御した実験室における主観評価実験 を基に、LEVに対応する総合的な物理指標として、 $\mathrm{LG}^{2}{ }^{2} \mathrm{SBTs}^{6}{ }^{6}$ など が提案されている。

既往の研究において、LEV は一対比較法により評価するのが一般 的であるが、これから得られる心理尺度値は相対的なものであり、 各実験間でのデータ比較は行えないので、LEVに関わる全てのパラ メータを組み合わせた実験条件において一対比較を行うべきである。 しかし、LEVに関する既往の研究においては、前述したパラメータ を個別に実験している例が多く、既存の物理指標が包括的に LEV を 評価できているかは、十分明らかではない。

そこで本研究では LEV に関わるパラメータを組み合わせた実験条 件を作成し既存の物理指標が各パラメータの LEV への寄与を包括的 に評価しているかを検討することにした。なお、上述したように全
てのパラメータを組み合わせた実験条件を作成するのが望ましいが、 比較対の数が膨大になるため、本実験では 2 個のパラメータを組み 合わせた条件を作成した。

実験 1 では残響時間、C80 および残響音の到来方向が LEV に与え る影響を調べた。

実験 2 および実験 3 では、残響エネルギの左右および前後の空間 的な分布が LEVに与える影響を調べた。

また得られた知見をもとに、LEV を評価する新たな物理指標の提 案を試みた。

\section{2. 实験の方法}

全ての㥶験は無響室内において、シミュレーション音場を用いて 行った。音源信号はDENON プロフェッショナルテスト CD 内に収録 されているオーケストラの無響室録音（ヘンデル「水上の音楽」第 6 曲、冒頭部分約 7 秒間) である。

初期反射音はディレイマシン(YAMAHA D5000)、残響音はリバー ブレーター(YAMAHA ProR3)により作成し、それらを直接音とともに ハードディスクレコーダー(AKAI DR8)に録音した。実験のインパ ルスレスポンスを図 1 に示す。また刺激の呈示レベルは76.8〜 79.8 $\mathrm{dBA}(\mathrm{slow})$ である。本実験では $80 \mathrm{~ms}$ 以降の残響部分の変化と LEV と

\footnotetext{
* 蜊類設計室 工修

$* *$ 近畿大学理工学部建築学科 助教授 $\cdot$ 工博

****近畿大学理工学部建築学科 教授・工博
}

Rui Sekkei Shitsu Co., Ltd., M. Eng.

Assoc. Prof., Dept. of Architecture, Faculty of Science and Engineering, Kinki Univ., Dr. Eng.

Prof., Dept. of Architecture, Faculty of Science and Engineering, Kinki Univ., Dr. Eng. 
対応を調べることを目的としたため、直接音および初期反射音のレ ベルを一定に保っている。そのため、残響時間や残響音到来方向は 聴取レベルに影響を与えないものの、残響部のエネルギーの増减 (C80 で土 $3 \mathrm{~dB}$ の変化) は聴取レべルを変化させている。従って、本 実験の結果は聴取レベル一定の条件下での結果に比較して C 80 の LEV への効果を大きく評価することになる。本研究では直接音およ び初期反射音のレベルを一定とするという条件で結果をまとめてい ることに留意されたい。

\section{1 実験装置}

実験 1 および実験 2 における装置のブロック図を図 2 に、実験 3 における装置のブロック図を図 3 に示す。スピーカは、被験者の頭 の位置を中心に半径 $2.1 \mathrm{~m}$ の同心円上に $30^{\circ}$ または $45^{\circ}$ の等間隔に 設置した。実験に際しては、7台のスピーカのうち必要なスピーカ を選択し直接音、初期反射音および残響音を提示した。

\section{2 被験者}

被験者は 20 歳〜 24 歳の聴覚に異常のない男子大学生 11 名である。 実験に先立ち、“みかけの音源の幅”と “音に包まれた感じ”の概 念図7)を被験者に提示し、“音に包まれた感じ”を“まわりから到来 する音に包まれている感じ、あるいは浸っている感じ”と教示した。

\section{3 刺激の評価方法}

本実験において、刺激の評価方法としてはシェッフェの一対比較 法 ${ }^{8)}$ を用いることにした。1 対の刺激を約 3 秒の間隔をおいて続け

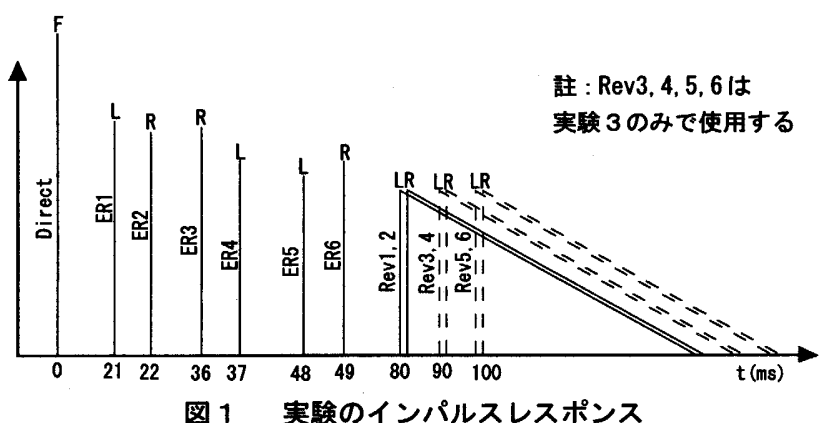

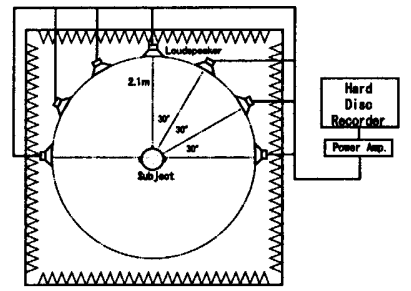

图 2 実験 1 および実験 2 の装置ブロック図

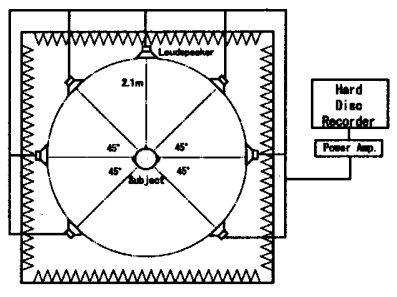

図 3 実験 3 の装昷ブロック図
て呈示し、先行する刺激を基準として、後続の刺激の音に包まれた 感じを、「1．非常に包まれた感じがある」、「2．包まれた感じがあ る小「3．少し包まれた感じがある」、「4．変わらない小「5．少し 包まれた感じがない、「6. 包まれた感じがない、「7．非常に包ま れた感じがない」の 7 段階で評価させた。また実験 1 および実験 2 では 36 個の刺激対を 1 セット、実験 3 では 28 個の刺激対を 1 セット として、合計 12 セットを 3 日に分けて行った。

刺激の呈示順序はランダムとし、順序効果を相殺するために、各 刺激対内での呈示順序を入れ替えた刺激対についても評価させた。 また各被験者について、一回目の解答と刺激の順序を入れ替えた 2 回目の解答が同一であるかを検定し、再現性が $50 \%$ 以下の回答者は、 正しい判断が出来ていないとみなし、集計からとり除いた。集計に 用いた被験者数は実験 $1 \mathrm{~A}$ が 7 名、1B が 11 名、1C が 10 名、 2 が 8 名、 $3 \mathrm{~A}$ が 6 名、3B が 9 名である。

3. 実験 1 : 残響時間、C80 および残響音の到来方向が音に包まれた

\section{感じに与える影恝}

残響時間、C80 および残響音の到来方向の 3 つのパラメータをそ れぞれ個別に制御して各被験者にLEV を評価させ、得られた心理尺

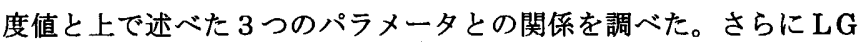
やSBTs との対応関係ついても検討した。

\section{1 実験条件}

実験 1 におけるスピーカの配置を図 4 に示す。実験に用いた音場 は直接音と 6 本の初期反射音、 2 本の非干涉性の残響音からなる。 直接音は正面 $\left(\alpha=0^{\circ}\right)$ のスピーカから放射し、また初期反射音は 前方 $\alpha= \pm 30^{\circ}$ 方向から放射した。

実験 1 における各刺激のパラメータを表 1 に示す。実験 $1 \mathrm{~A}$ では $\mathrm{C} 80$ の值を固定し、残響時間および残響音の到来方向 $\alpha$ を同時に変 化させた。実験 1B では残響時間を固定し、C80 および到来方向 $\alpha$ を 同時に変化させ、実験 $1 \mathrm{C}$ では到来方向 $\alpha$ を固定し、残響時間および $\mathrm{C} 80$ を同時に変化させた。

\section{2 結果と考察}

実験 1A、1B および 1C の結果を図 5〜 7 に示す。なお、実験結果 の表示において縦軸 LEV の範囲は実験で用いた 7 段階評価に合わせ たー3〜3ではなく、見やすさを優先して $-2 \sim 2$ としている。これら の図より、残響時間、C80、残響音の到来方向のいずれも LEVに対 して影響があることが明らかである。

実験 $1 \mathrm{~A}$ および $1 \mathrm{C}$ の結果（図 5，7）より、残響時間の LEV に対 する寄与は確認できるが、実験 1C では実験 $1 \mathrm{~A}$ より残響時間による $\mathrm{LEV}$ の心理尺度値の変化量は小さい。これは一対比較を基に求めた

\section{表 1 実験 1 の刺激の種類}

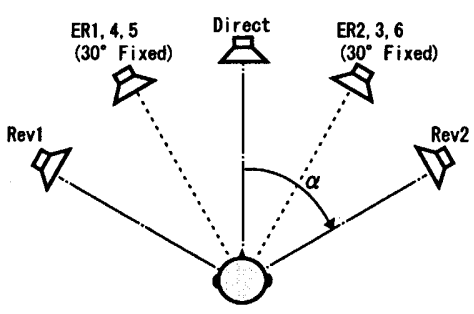

図4実験 1 のスピーカ配置

\begin{tabular}{|c|c|c|c|c|c|c|c|c|c|}
\hline \multirow[b]{2}{*}{ Stimulus } & \multicolumn{3}{|c|}{ Experiment 1A } & \multicolumn{3}{|c|}{ Experiment 1B } & \multicolumn{3}{|c|}{ Experiment 1C } \\
\hline & $\begin{array}{l}\text { RT } \\
\text { (s) }\end{array}$ & $\begin{array}{l}\mathrm{C} 80 \\
(\mathrm{~dB})\end{array}$ & $\begin{array}{c}\alpha \\
\text { (degree) }\end{array}$ & $\begin{array}{l}\text { RT } \\
\text { (s) }\end{array}$ & $\begin{array}{l}\text { C80 } \\
\text { (dB) }\end{array}$ & $\begin{array}{c}\alpha \\
\text { (degree) }\end{array}$ & $\begin{array}{l}\text { RT } \\
\text { (s) }\end{array}$ & $\begin{array}{l}\mathrm{C80} \\
(\mathrm{dB})\end{array}$ & $\begin{array}{c}\alpha \\
\text { (degree) }\end{array}$ \\
\hline 1 & 1.5 & 0 & 30 & 2.0 & 3 & 30 & 1.5 & 3 & 90 \\
\hline 2 & 1.5 & 0 & 60 & 2.0 & 3 & 60 & 1.5 & 0 & 90 \\
\hline 3 & 1.5 & 0 & 90 & 2.0 & 3 & 90 & 1.5 & -3 & 90 \\
\hline 4 & 2.0 & 0 & 30 & 2.0 & 0 & 30 & 2.0 & 3 & 90 \\
\hline 5 & 2.0 & 0 & 60 & 2.0 & 0 & 60 & 2.0 & 0 & 90 \\
\hline 6 & 2.0 & 0 & 90 & 2.0 & 0 & 90 & 2.0 & -3 & 90 \\
\hline 7 & 3.0 & 0 & 30 & 2.0 & -3 & 30 & 3.0 & 3 & 90 \\
\hline 8 & 3.0 & 0 & 60 & 2.0 & -3 & 60 & 3.0 & 0 & 90 \\
\hline 9 & 3.0 & 0 & 90 & 2.0 & -3 & 90 & 3.0 & -3 & 90 \\
\hline
\end{tabular}




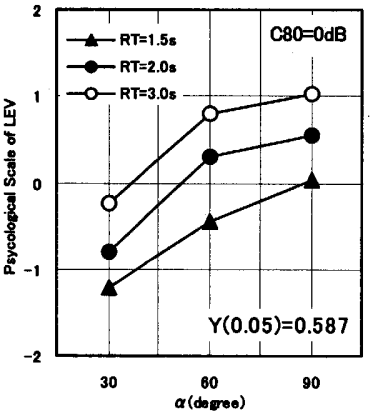

图 5

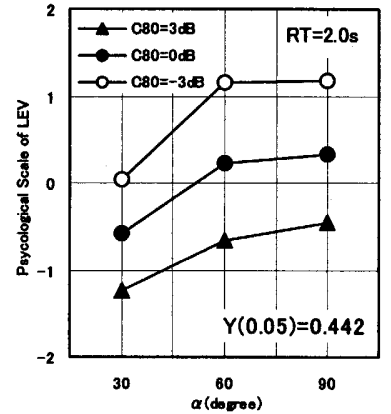

图 6 実験 1B の心理尺度值

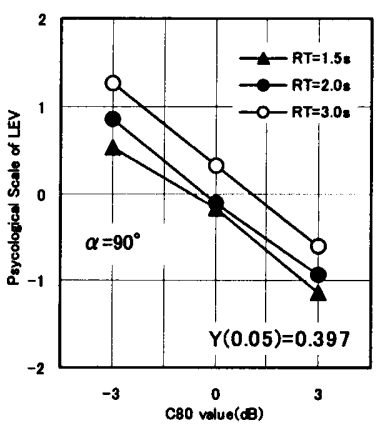

図 7 実験 $1 \mathrm{C}$ の心理尺度值
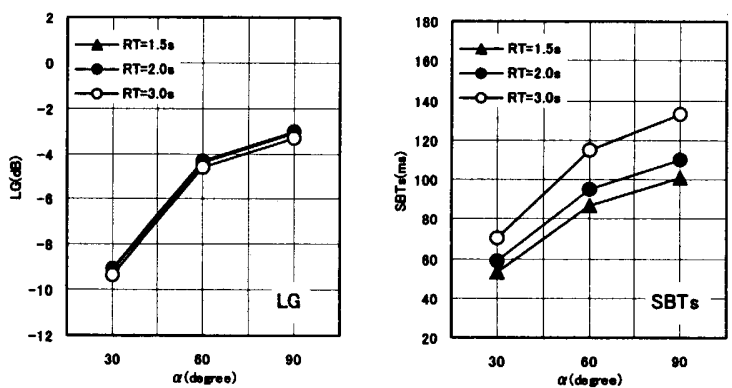

図8実験 $1 A$ におけるLGおよひ SBTs の変化
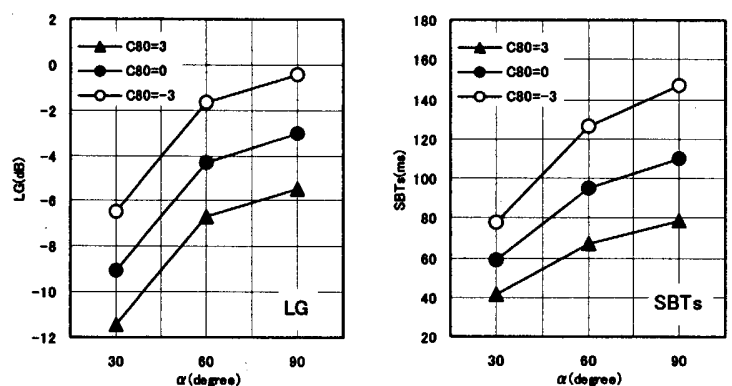

図 9 実験 1BにおけるLGのおよびSBTs の変化
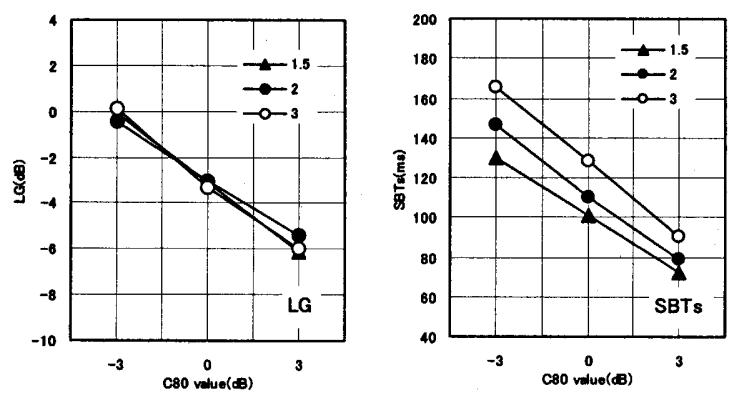

图 10 実験 $1 C$ におけるLGおよびSBTs の変化
心理尺度値は相対的なもので、各実験において組み合わせたパラ メータにより、当該のパラメータの心理尺度值への寄与が異なるた めである。つまり $\mathrm{C} 80$ の $+3 \mathrm{~dB} \sim-3 \mathrm{~dB}$ の変化は、到来方向の $30^{\circ} \sim$ $90^{\circ}$ の変化よりも LEV を大きく変化させるため、その結果、残響時

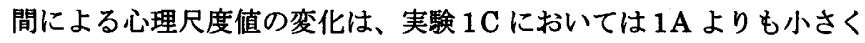
なっている。Bradleyは残響時間と C80、残響音到来方向を変化させ た実験を行い、残響時間の $1.5 \mathrm{~s}$ の変化に対する LEV の心理尺度值の 変化が 0.28 しかないことを理由に、残響時間が LEVに与える影響は 小さいと結論付けている5（彼の提案した LG では C80 が一定ならば、 残敬時間はその值に影響を与えない)。彼の用いた実験条件では、 C80 の LEV に対する影響が大きかったため、結果的に残響時間の寄 与が小さくなったと考えられるが、彼の結果においても残響時間の 影锌がないとはいえない。本実駼の結果から明らかなように、C80 を一定とした条件でも残響時間が長くなると LEV が增加することが 明らかである。

次にC80 に注目すると、実験 1B、1C の結果（図 6，7）から明ら かなように、 C80 の值が小さくなると (残警部分のエネルギが大きく なると）LEVは增加する傾向にある。またその増加傾向は実験 $1 \mathrm{C} の$ 結果を見ても明らかなようにほほ直線的であるといえる。

最後に到来方向 $\alpha$ が $30^{\circ}$ から $90^{\circ}$ まで、角度が大きくなるととも にLEV も增加している。しかし、LEV の変化は $30^{\circ}$ から $60^{\circ}$ の間で は比較的大きいが、 $60^{\circ}$ から $90^{\circ}$ の間では小さくなっている。

以上、残警時間、C 80 および残響音到来方向はそれぞれ LEV に寄 与することが確認された。

実験 $1 \mathrm{~A} 、 1 \mathrm{~B}$ および 1C の各音場の LG およびSBTs の計算值を図 8 〜 10 に示す。まず残繁時間との関係では LG は C80 の值が一定なら ば残響時間が変化してもその值は変化しない。一方 SBTs は時間重心 Ts を用いているため、残響時間が大きくなるとその值も大きくなる (図 8，10)。LGは残敬時間の影響を評価できないが、SBTs は残響時 間の影響を評価しているといえる。つぎにC80 に注目すると、LG、 SBTs ともにC80 の值が大きくなるとその值は小さくなる(図 9，10)。

最後に残響音到来方向に注目すると、SBTs、LG ともに $90^{\circ}$ で最大 となり LEV の実験結果の傾向とほほ一致している(図 8，9)。

\section{4. 実験 2 ：残靁音の左右のエネルギ分布が音に包まれた感しに与 える格带}

残警部の左右のエネルギ分布および到来方向を変化させて LEV の影響を調べた。なお $\mathrm{C} 80$ および残響時間は一定に保っている。

\section{1 実験条件}

実験に用いた音場は実験 1 と同様に直接音と 6 本の初期反射音、 2 本の非干涉性の残響音からなる。直接音は正面のスピーカから放 射し、また初期反射音は $330^{\circ}$ 方向から放射した。残響音の到来方 向は $\pm 30^{\circ} ， \pm 60^{\circ} ， \pm 90^{\circ}$ の3条件である。

実験に用いた刺激のパラメータを表 2 に示す。左右のトータルの 残響エネルギは一定に保ち、左右の残響音のレベル差を $0 \mathrm{~dB} 、 4 \mathrm{~dB}$ 、 $9 \mathrm{~dB}$ と変化させた。 $\mathrm{C} 80$ 值は $0 \mathrm{~dB}$ 、また残響時閒は 2.0 秒である。

\section{2 結果と考察}

実験 2 の結果を図 11 に示す。同図は横軸に残響音到来方向、縦軸 にLEV の心理尺度值、パラメータに左右の残響音のレベル差をとっ ている。図より、左右の残響音のレベル差が大きくなるほど（左右 
表 2 実験 2 の刺激の種類

\begin{tabular}{ccccc}
\hline \multirow{2}{*}{ Stimulus } & \multicolumn{5}{c}{ Parameter } \\
\cline { 2 - 5 } & Lch level(dB) & Rch level(dB) & $\mathrm{L} / \mathrm{R}(\mathrm{dB})$ & $\alpha$ (degree) \\
\hline 1 & 0 & 0 & 0 & 30 \\
2 & 1.5 & -2.5 & 4 & 30 \\
3 & 2.5 & -6.5 & 9 & 30 \\
4 & 0 & 0 & 0 & 60 \\
5 & 1.5 & -2.5 & 4 & 60 \\
6 & 2.5 & -6.5 & 9 & 60 \\
7 & 0 & 0 & 0 & 90 \\
8 & 1.5 & -2.5 & 4 & 90 \\
9 & 2.5 & -6.5 & 9 & 90 \\
\hline \hline
\end{tabular}

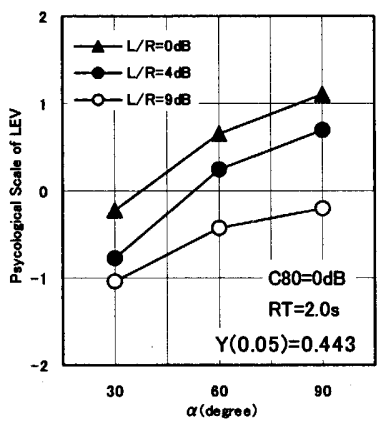

図 11 実験 2 の心理尺度值
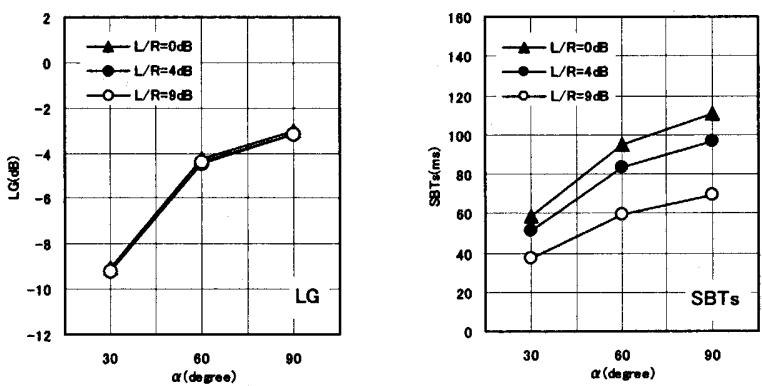

图 12 実験 2 におけるLGおよひ SBTs の変化

のエネルギバランスが悪くなるほど）LEV は低下することが明らか である。またその低下量は残響音到来方向が $90^{\circ}$ のときに最も大き く、30 の時に最も小さい。残響時間、C 80 および残響音の到来方 向の他に、残響エネルギの左右のバランスも LEV に影響することが 示された。本実験結果は羽入らの知見 ${ }^{9)}$ と一致する。

実験 2 の各音場の LG およびSBTs の計算值を図 12 に示す。LG は トータルエネルギを評価するものであるため、当然の事ながら、左 右のエネルギバランスには反応しない。一方 SBTs は左右のエネルギ バランスが悪くなるほど小さくなる。またその変化傾向も実験結果 とほぼ一致している。LG は左右のエネルギ分布が LEV に与える影 響を評価できないが、SBTs は評価しているといえる。

\section{5. 実験 $3 ：$ 残辢音の前後のエネルギ分布が音に包まれた感じに与 える影罾}

残響音の前後のエネルギ分布と併せて残響時間もしくは C 80 の值 を変化させて LEV への影響を調べた。同時に変化させるパラメー 夕は、実験 3A では残響時間、実験 3B では C80 である。

\section{1 実験条件}

実験 3 における各スピーカの配置を図 13 に示す。実験に用いた 音場は直接音と 6 本の初期反射音、 2 本〜 6 本の残響音からなる。 本実験では全ての条件で直接音は正面のスピーカから、初期反射
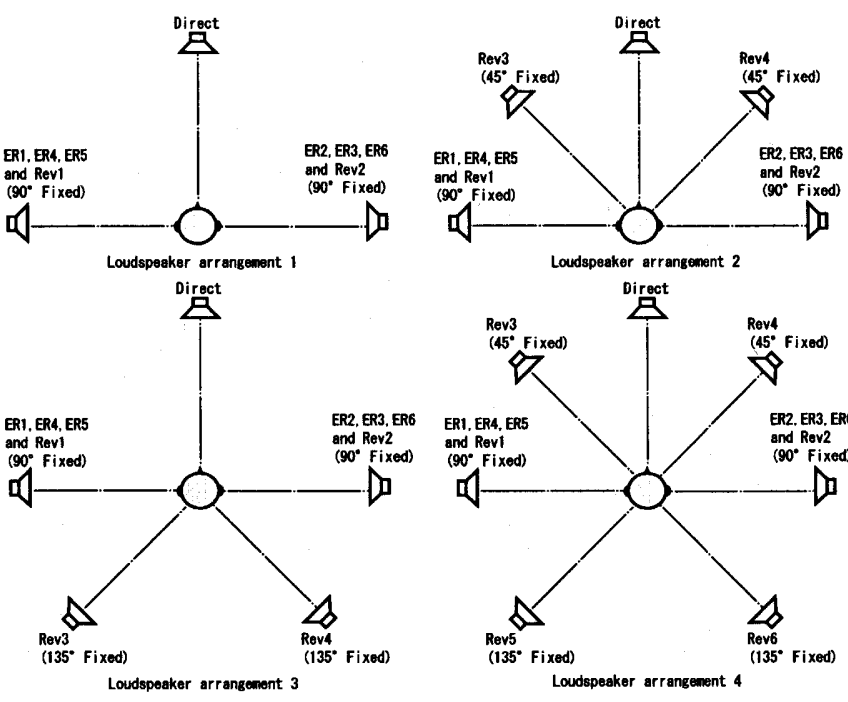

図 13 実験 3 のスピーカ配置の種類

\section{表 3 実験 3 の刺激の種類}

\begin{tabular}{cccc}
\hline \hline \multirow{3}{*}{ Stimulus } & \multicolumn{3}{c}{ Parameter } \\
\cline { 2 - 4 } & $\begin{array}{c}\text { Loudspeaker } \\
\text { arrangement }\end{array}$ & RT(s) & C80(dB) \\
\hline 1 & 1 & Experiment 3A \\
2 & 2 & 2 & 0 \\
3 & 3 & 2 & 0 \\
4 & 4 & 2 & 0 \\
5 & 1 & 2 & 0 \\
6 & 2 & 3 & 0 \\
7 & 3 & 3 & 0 \\
8 & 4 & 3 & 0 \\
& & 3 & 0 \\
1 & 1 & 2 & 0 \\
2 & 2 & 2 & 0 \\
3 & 3 & 2 & 0 \\
4 & 4 & 2 & 0 \\
5 & 1 & 2 & -3 \\
6 & 2 & 2 & -3 \\
7 & 3 & 2 & -3 \\
8 & 4 & 2 & -3 \\
\hline \hline
\end{tabular}

音は土90 方向から放射した。各刺激のパラメータを表 3 に示す。 各音場条件で残響を放射するスピーカの数は異なるが、C 80 の值が 等しければ、残響のトータルのエネルギは等しくなるように、ま た、各音場条件内では、個々の残響用スピーカが放射するエネルギ は全て等しくなるよう調整した。

\section{2 結果と考察}

実験 3A および 3B の結果を図 14、15 に示す。同図は横軸にスピー カの配置、縦軸に LEV の心理尺度値をとり、パラメータはそれぞ れ残響時間と $\mathrm{C} 80$ 值である。 4 種類のスピーカ配置の内では、 $90^{\circ}$ 方向にのみ残響音が集中している配置 1 のときが最も大きい。次に 大きいのは $90^{\circ}$ 方向に加えて前方 $45^{\circ}$ 、後方 $135^{\circ}$ と分散させた配 置 4 のときである。続いて $90^{\circ} 、 45^{\circ}$ と前方に分布させた配置 2 が大きくなっている。最後に最も LEV が小さくなるのは $90^{\circ} 、 135$ 。と後方に分布した配置 3 である。実験 $3 \mathrm{~A}$ および $3 \mathrm{~B}$ のヤードス ティック值（有意水準 5\%）は、それぞれ 0.593，0.477でありスピー 力配置 1 と 3 の間で有意差が認められる。また実験 $3 \mathrm{~A}$ の残響時間 3 秒の条件では配置 3 と 4 の間で有意差が認められる。LEV の変 化傾向は残響時間や C 80 の值に関わらず同様であり、結果を総合的 


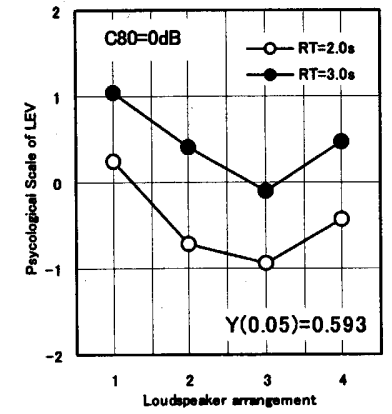

図 14 英験 3A の心理尺度値

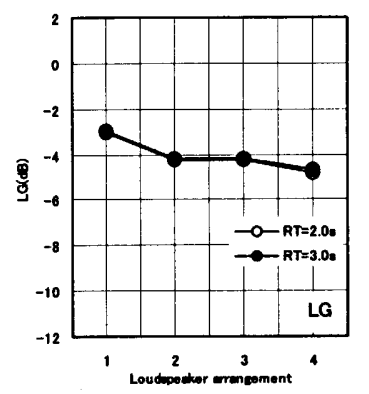

図 16 実験 $3 A$ におけるLGおよびSBTs の変化
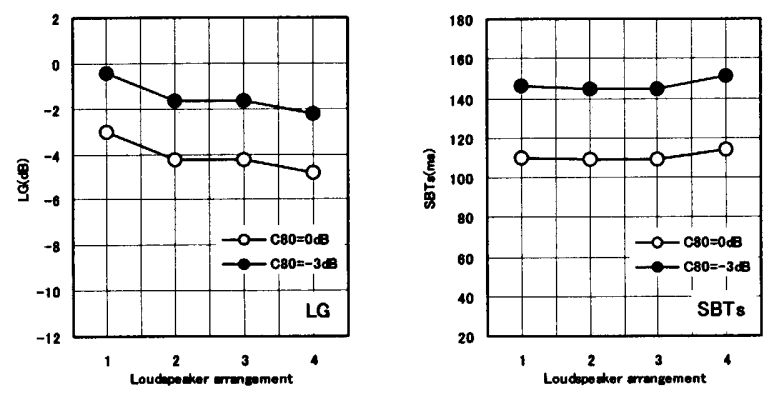

図 17 实験 3B におけるLGおよびSBTs の変化

に見て、LEV は配置 1 で最大、配置 3 で最小、配置 2 と 4 ではそ の中間的な值となるものと考えてよいと思われる。

スピーカ配置 2 は配置 3 よりも LEV が大きく、残響音の到来方 向は前方から到来する方が後方よりも LEV に対する効果が大きい ことを示している。これは後方から到来する残響音のエネルギが

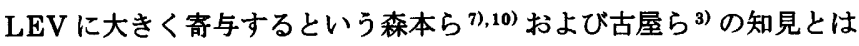
異なった結果となっている。

本実験のスピーカ配置 $1,2,3$ の結果から、単独の残響音到来方向 としては $90^{\circ}, 45^{\circ}, 135^{\circ}$ の順に LEVに対する効果が大きいことが わかる。この結果は、単独の残響音到来方向の LEV への奇与は前 後対象であるとする Bradley ${ }^{2)}$ や羽入ら ${ }^{6)}$ の知見とは異なっている。 一方、単独では LEV に対する効果の小さい $135^{\circ}$ 方向にも残響エネ ルギを分散させた配置 4 は、それを含まない配置 2 よりも LEV の 心理尺度值が明確な有意差はないものの 4 条件の全てで若干高く なっており、残響の前後のエネルギ分布が LEV に寄与することを 示唆している。この結果は、LEV は個々の反射音の効果の単なる 和ではなく、空間バランスが影響するという羽入らの知見 ${ }^{6)}$ とも一 致するものである。

実験 3 におけるLG およびSBTs の計算值を図 16 および図 17 に示 す。まずLG はスピーカ配置 1 で最大值をとり、スピーカ配直 4 で
最小值をとる。しかしその変化はごく小さい。また配置 2 と 3 の間 に差は見られない。さらに C80 の值が小さくなると LG は大きくな るが、残響時間が変化しても LG は変化しない。SBTs は配置 $1 \sim 4$ の閒で值の変化はほとんどない。両者とも LEV の実験結果とは大 きく異なった振舞い方をしている。以上より残響音の前後のエネル ギ分布の LEV への寄与に関してはLG、SBTs ともに評価できないと いえる。

\section{LEV に対応する物理指標の検討}

本章では上述の実験で得られた知見をもとに LEVに対応する物 理指標について検討を行う。

\section{1 LEV 評価指㩲の必要条件}

本実験で得られた知見より、LEV 評価指標が満たすべき条件は 以下の通りである。

a. 残警音の到来方向に関しては、 $\pm 90^{\circ}$ 付近でLEVに対する寄与 は最大となる。(実験 $1 \mathrm{~A} 、 1 \mathrm{~B}$ )

b. 残蔀時間が長くなると LEV は大きくなる。(実験 $1 \mathrm{~A} 、 1 \mathrm{C}$ )

c. 残響部分のエネルギが大きくなると LEV は大きくなる。( 実験 1B、1C)

d. 残響音の左右のエネルギバランスが悪くなると LEV は小さくな る。(実験 2)

e. 残響音の前後のエネルギバランスが悪くなると LEV は小さくな る。(実験 $3 A 、 3 B$ )

f. 前方からの残響音のほうが後方からの残響音よりも LEV に対す る奇与は大きい。(実験 3A、3B)

既存の物理指標が本実験で得られた知見とどれだけ一致するかを検 討すると、LGは知見 b、d、e、f と矛盾する。また SBTs は知見 $\mathrm{e} 、 \mathrm{f}$ と矛盾する。よって今回の実験結果と矛盾なく対応する LEV 評価 指標について険討をおこなう。なお鉛直方向についても検討する必 要があるが、今回はまず水平面のみを対象とする。

\section{2 LEV 評価指標}

まず反射音の時間構造にかかわる知見 $\mathrm{b} 、 \mathrm{c}$ を考える。SBTs はこ の部分については、ほぼ定量化できているといえる。そこで、本指 標でもSBTsにならい時間重心Ts の考え方を取り入れる。但し、積 分範囲は $80 \mathrm{~ms}$ 以降としており、残響部分のみを対象としている。 $i$ 方向から到来する残響音を次式により評価する。

$$
L T s_{i}=\frac{\int_{80}^{\infty} t \cdot p_{i}^{2}(t) d t}{\int_{0}^{\infty} p^{2}(t) d t}
$$

ここで $p(t):$ 無指向性インパルス応答、 $p_{i}(t): i$ 方向より到来する反 射音。

つぎに残響音の到来方向に関する重み付けについて考える。知 見 a と $\mathrm{f}$ を併せて考虑すると、 $90^{\circ}$ よりも若干前方寄りの方向で LEV に対する効果が最大となっていることが推測される。そこで、羽入 $ら^{6)}$ の方法を参考に次式により $f_{i}$ を定量化した。同式では $\pm 75^{\circ}$ が 重み付けのピークとなる点が羽入らの方法と異なっている。

$$
f_{i}=L T s_{i} \cdot \frac{\left(1+\left|\sin \theta^{\prime}{ }_{i}\right|\right)}{2}
$$


但 $\left|\theta_{i}\right| \leqq \frac{5}{12} \pi$ の場合

$$
\theta^{\prime}{ }_{i}=\frac{6}{5} \theta_{i}
$$

$\left|\theta_{i}\right|>\frac{5}{12} \pi$ の場合

$$
\theta^{\prime}{ }_{i}=\frac{\left(6 \theta_{i}+\pi\right)}{7}
$$

ここで $\theta_{i}:$ 残響音の到来方向 (正面からの角度)である。

つぎに知見 $d 、 e$ より残響音の前後および左右のエネルギ分布を定 量化する。受聴者を中心とする単位距離の円を考え、その円周上の 対応する方向に(2) 式により求めた残響音評価量 $f_{i}$ を分布させる。こ の $f_{i}$ の重心を求め、この重心位置により、残響音のエネルギの空間 的分布を評価できるものと考えた。重心位置は、左右方向 $\left(S_{x}\right)$ と前 後方向 $\left(S_{y}\right)$ に関して次式により求まる。

左右方向

$$
S_{x}=\frac{\sum_{i=1}^{n} f_{i} \cdot \sin \theta_{i}}{\sum_{i=1}^{n} f_{i}}
$$

前後方向

$$
S_{y}=\frac{\sum_{i=1}^{n} f_{i} \cdot \cos \theta_{i}}{\sum_{i=1}^{n} f_{i}}
$$

全ての残響音による LEV は、各方向の残響音の奇与の総和 $\Sigma f_{i}$ と上式により求めた空間重心を考虑したファクタとの積で評価でき るものと考えた。実験結果と最も高い相関を示すように重心位置に 対する保数を検討し、最終的には重心に関するファクタとして、次 式を得た。

$$
k=\left(1-0.3\left|S_{x}\right|-0.2\left|S_{y}\right|\right)
$$

LEV に対する指標をSDR（Spatial Distribution of Reverberation）と呼 ぶこととし、これを次式で定義する。

$$
S D R=k \cdot \sum_{i=1}^{n} f_{i}
$$

\section{3 各実験の心理的距離尺度値と SDR の対応}

本実験の各音場条件における SDR の計算值を LEV の心理尺度值と の相関図とともにそれぞれ図 18 から図 23 に示す。これらをみると SDR の変化傾向と LEV の心理尺度值の変化傾向が良く対応している ことがわかる。特にLG やSBTs などの従来の物理指標では評価でき なかった実験 $3 \mathrm{~A} 、 3 \mathrm{~B}$ における残響音の前後のエネルギ分布の変化傾 向に対してもSDRの変化傾向はよく対応している。

各物理指標と LEV の心理尺度值の相関係数を表 4 に示す。同表よ
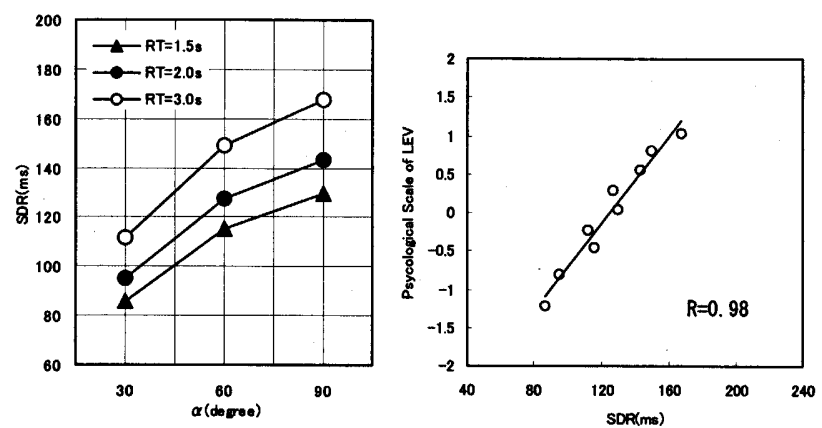

図 18 実験 $1 \mathrm{~A}$ におけるSDR の変化および心理尺度値との相関関係
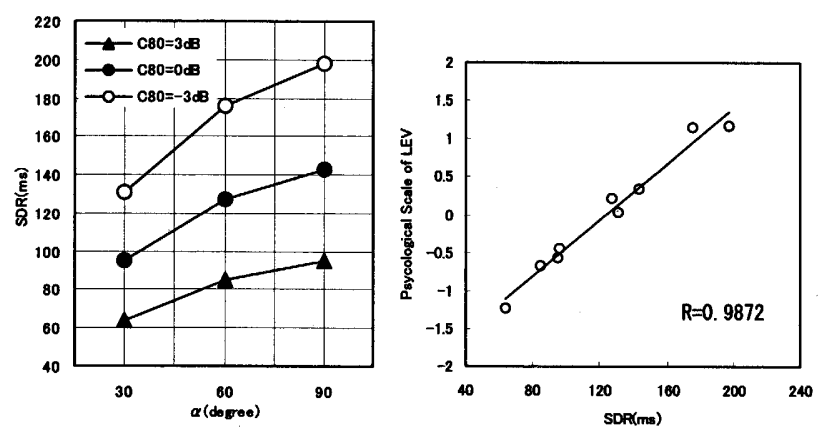

図 19 実験 1 B におけるSDR の変化および心理尺度値との相関関係
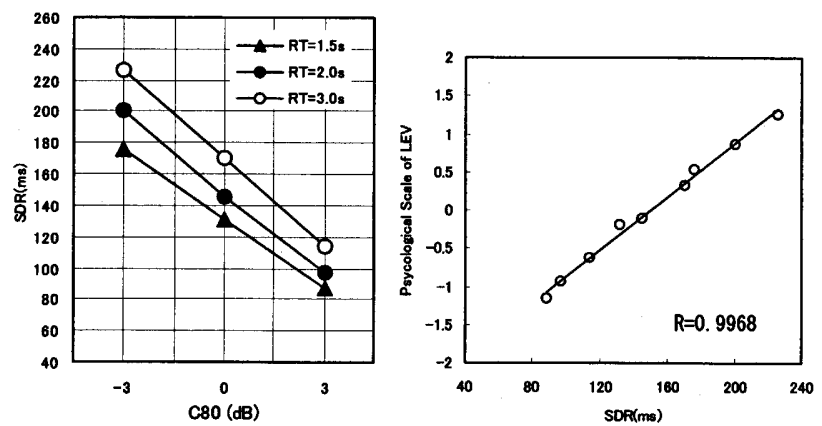

図 20 実験 $1 \mathrm{C}$ における SDR の変化および心理尺度値との相関関係
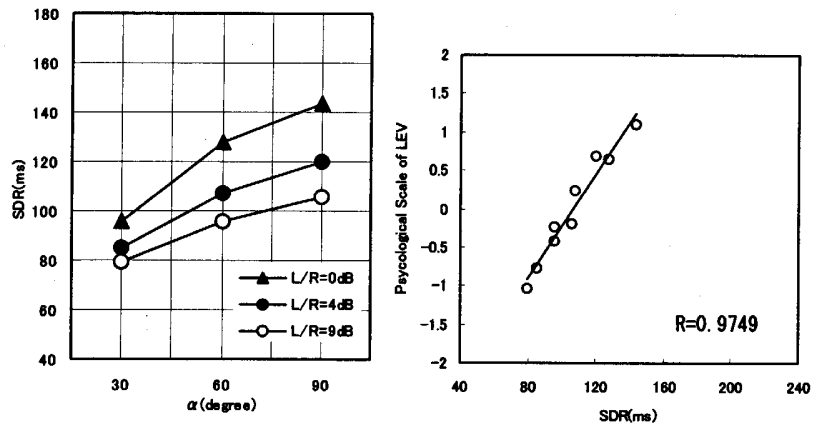

図 21 実験 2 におけるSDR の変化および心理尺度值との相関関係
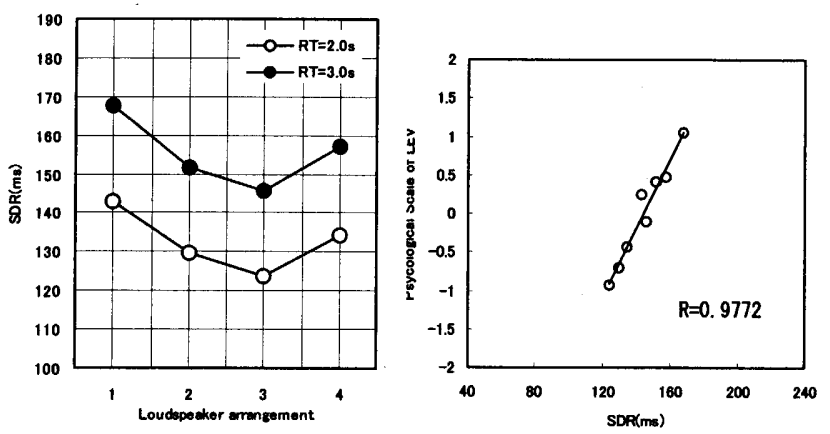

図 22 実験 $3 A$ におけるSDR の変化および心理尺度値との相関関係 

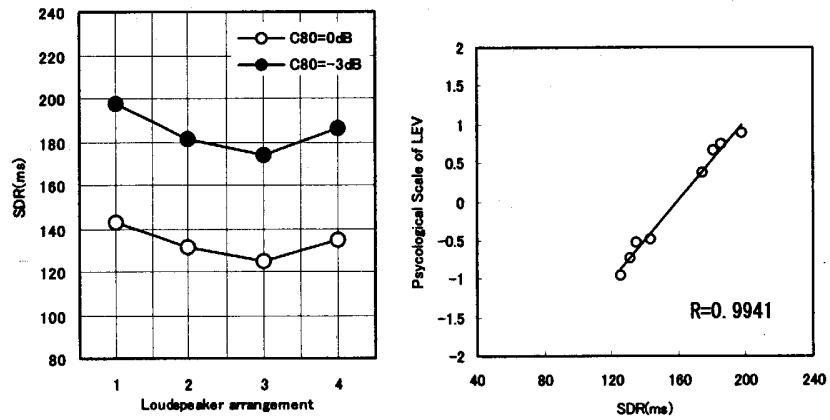

図 23 実験 3B におけるSDR の变化および心理尺度値との相関関係

\section{表 4 各物理指樭と LEV 心理尺度值との相関係数}

\begin{tabular}{cccc}
\hline \multirow{2}{*}{ experiment } & \multicolumn{3}{c}{ physical measures for LEV } \\
\cline { 2 - 4 } & LG & SBTs & SDR \\
\hline 1A & 0.751 & 0.956 & 0.980 \\
1B & 0.940 & 0.969 & 0.987 \\
1C & 0.941 & 0.996 & 0.997 \\
2 & 0.753 & 0.993 & 0.975 \\
3A & 0.534 & 0.756 & 0.977 \\
3B & 0.909 & 0.973 & 0.994 \\
\hline \hline
\end{tabular}

り実験 2 においてはSBTs よりも若干、相関俰数の值は小さいが、そ れ以外の実験ではすへてにおいて SDR の值が LG およびSBTs の值を 上回っている。特に、前後の残響音のエネルギ分布に関しては、SBTs は評価できないが、SDR はLEV の心理尺度值と非常に高い相関を示 している。

SDR は本実験の全ての結果とよく対応するものであるが、実験 3 における LEV の変化傾向は従来の知見とは異なっていることは述へ ておく必要があると思われる。すなわち「前方から到来する残響が 後方よりも LEVに対する効果が大きい」という本実験の結果は従来 の知見とは異なっており、これが確かなものであることを主張する にはさらに実験を重ねることが必要であろう。また、SDR の適用範 囲についても検討が必要と思われる。例えば、残響音の空間的バラ ンスを評価するファクタ $\boldsymbol{k}((7)$ 式) は0.5よりも小さくなることはな いため、残響音の空間的な偏りが非常に大きい場合には LEV と SDR 值との対応が悪くなることが予想される。さらに、今回は $80 \mathrm{~ms}$ 以降 の残響部分の変化に主眼をおいて実験をおこなったが、初期反射音 が LEVに影響を及ぼすという報告もあり 11),12),13)、LEVに関する包括的 な指標とするためには、初期反射音部分に関する検討も必要と思わ れる。

\section{7. まとめ}

残響音の到来方向、残響時間、C 80、残響音の前後および左右の エネルギ分布が音に包まれた感じに与える影響を 6 種類の実験を行 うことによって調べ、以下の結果を得た。

1）残響音の到来方向に関しては、 $\pm 90^{\circ}$ 付近でLEVに対する寄 与は最大となる。

2 ）残響時間が長くなると LEV は大きくなる。

3 ）残響部分のエネルギが大きくなると LEV は大きくなる。

4 ）残響音の左右のエネルギバランスが悪くなると LEV は小さく なる。
5 ）残響音の前後のエネルギバランスが悪くなると LEV は小さく なる。

6 ）前方からの残響音のほうが後方からの残響音よりも LEV に対 する寄与は大きい。

これらの結果のうち、1）～5）は概ね既往の研究と一致するも のであるが、6）は異なっている。

これらの知見をもとに方向別の Ts を用いて、空間重心で重み付け を行うことにより LEV と対応する物理指標 SDR (Spatial Distribution of Reverberation）を提案した。SDRは今回行ったLEVに関する実験 結果の全てと高い相関を示すことが確認された。

\section{【文献】}

1）森本政之、藤森久嘉、前川純一 “みかけの音源の幅と音に包まれた感じ の差異” 日本音響学会誌 46 巻 6 号 pp.449-457, 1990.6

2) J. S. Bradley and G. A. Soulodre, "The influence of late arriving energy on spatial impression" J. Acoust. Soc. Am. 97 pp.2263-2271, 1995

3) H. Furuya, K. Fujimoto, Y. J. Choi and N. Higa, "Arrival direction of late sound and listener envelopment”, Applied Acoustics 62 pp.125-136, 2001

4) 神谷宗宏、河本真由美、森本政之、中川浩一“残響音の各種パラメータ が音に包まれた感じに及ぼす影響”建築音響研究会资料資料番号 AA2001-4, 2001

5) J. S. Bradley and G. A. Soulodre, "Objective measures of listener envelopment" J. Acoust. Soc. Am. 98 pp.2590-2597, 1995

6) 羽入敏樹、木村翔、千葉俊 “反射音の空間バランスに着目した音に包ま れた感じの定量化方法”日本建築学会計画系論文集 第 520 号, pp.9-16, 1999

7) M. Morimoto, K. Iida, K. Sakagami, "The role of reflection from behind the listener in spatial impression" Applied Acoustics 62 pp.109-124, 2001

8）難波精一郎、桑野園子“音の評価のための心理的測定法”コロナ社, 1998

9）星和磨、伊藤豊成、木村翔、羽入敏樹 “反射音のレベルバランスが音に 包まれた感じに及ぼす影響” 日本建築学会大会学術講演梗概集 D-1, pp.39-40, 1999

10）森本政之 “音場の前後エネルギー比が音に包まれた感じにおよぼす影 響” 日本建筑学会近幾支部研究報告集 第 35 号・計画系, pp.29-32, 1991.6 11) Furuya, H., Fujimoto, K., Takeshima, Y. \& Nakamura, H., "Effect of early reflections from upside on auditory envelopment." J. Acoust. Soc. Jpn. (E) 16, pp.97-104, 1995

12) Morimoto, M., Iida K., \& Sakagami K., "The role of reflections from behind the listener in spatial impression.", Applied Acoustics 62. pp.109-124, 2001

13）羽入敏樹、星和磨、関口克明、“初期反射音が音に包まれた感じに及 ぼ寸影響、” 日本音響学会 2002 年秋期研究発表会講演論文集 II , pp.901902, 2002.9

(2005年 3 月 15 日原稿受理，2005年 9 月 26 日採用決定） 